\title{
MAGNETIZING THE INTEREST AND RETENTION OF LECTURER IN PRIVATE HIGHER EDUCATION
}

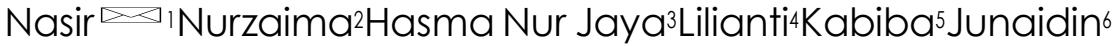

Universitas Muhammadiyah Kendari

\section{$\unrhd$ dhion_zir@yahoo.com}

\begin{abstract}
Education This study aimed to explore the strategy to maintain lecturers, particularly in private higher education. It is important because the growth of private universities makes qualified lecturers contested. Responding to that crisis, leaders imposed to construct a strategy to keep them. The required data were collected by interviewing selected respondents determined by the key informant. The instrument used in gathering data was a semi-structured interview. The data then analyzed with the inductive model by Miles, Huberman, \& Saldana. The result of the study reveals that: higher education should respond to what is prompting lecturers to move. They must take responsibility for every lecturer resigning and to intervene immediately to find out the reasons that make the lecturer to resign. In terms of the strategy to counter the lecturer's switch out, the researcher constructed a strategy to magnetize them to remain through concerning more seriously on some aspects, for instance: payment, leadership style, career development, conducive-work life, adequate well-resourced libraries, recognition, and workload. All these efforts addressed to motivate them in working then decide to remain in the institution. Lastly, the researcher also recommends to others to test the conclusion by applying a quantitative approach.
\end{abstract}

Keywords: Human Resource Management, Retention, Private Higher Education.

INTRODUCTION In Organizations is facing the challenge of employee retention due to increased competition in the market (Maqsood et al., 2015). Hence, the human resources manager must know how to attract and keep good employees because these are the employees who can make or break the organization's goodwill (Wisnefski, 2008; Rasli et al., 2014). Stauss et all. (2001) has defined retention as customer liking, identification, commitment, trust, readiness to recommend, and repurchase intentions, with the first four being emotional-cognitive retention constructs, and the last two being behavioral intentions. Meanwhile, Michael (2018) states that retention is an endeavor engaged by an organization to create an environment that appoints employees for the long term. Chipunza \& Samuel (2009) even highlight that it is not only the government sector, but private is also facing difficulty in retaining skilled employees.

Linking to the universities' growth in Indonesia, it requires them to compete (Rahayuningtyas \& Triana; 2017). This circumstance leaves tension over universities' broader societal duties (Barber \& Rizvi: 2013). One strategy for universities dealing with such competition is by creating excellence and resources (Bratianu, 2005). Reported by Kemenristek DIKTI (2017), 122 state universities have been registered in Indonesia, consisting of 63 universities, 13 institutes, three community academies, and 43 polytechnics whereas the number of private universities is 3,154 which includes: 492 universities, 65 institutes, 1,431 high schools, 1,007 academies, 12 community academies, and 147 polytechnics.

The ministry of research, technology, and 
higher education stipulate one of its national targets is to reduce the number of private universities to 1,000 by the end of 2019. The strategy to achieve it is through merging and unifying of private universities and the acquisition of universities (Kemeristek DIKTI, 2018). Merging higher education intends to compete with being more world-class university (Pinheiro \& Aarrevaara, 2015). Ensure long-term financial sustainability, increasing their attractiveness, create a tension in campuses' purposes (Zeeman \& Benneworth, 2017), achieve administrative, economic and academic benefits (Mok, 2005), maintaining lecturer-student ratio, and efficiently supervising it (Team of Higher Education Policy Review, 2018a).

In terms of managing private universities, the government strictly has granted individual autonomy to non-profit legal entities or foundations to administers institutional management, especially non-academic deals such as financial management, personnel management, and asset/infrastructure management (UU DIKTI, 2012). However, the management of private higher education managed by foundations must still refer to the national standards of higher education that have been set by the government concerned with academic affairs.

It has pointed one of the autonomies that the government has given to private higher education was the management of human resources together with the management of lecturers, staff, and faculties. The increase in universities' growth has made competition tighter. Among universities, each other "grabs lecturers" by offering higher salaries (Edy, 2017; Calhoun, 2009). Therefore, lecturers' management must get attention to win the competition (Khan, Ahmed, \& Sarker, 2010). Lawler \& Fuchs (2010) highlighted that lecturers highly motivated due to university management placed the highest priority on lecturers to sustain and enhance faculty excellence. Referring to the previous narrative, it seems that the challenges of private universities today are not merely how to make the lecturer more comfortable and passionate in implementing the three pillars of higher education, but also to stimulate the best graduates to become a lecturer.

Mkulu (2018) reported that lecturers are moving from private to public universities, while other lecturers change their professional work. Meanwhile, Owuor (2010) found that there was a high movement of lecturers from African universities overseas due to inadequate pay, poor policies, and adverse working conditions. Cassidy (2011) stated that educators (teachers and lecturers) turn out to other institutions due to lack of training, career development opportunities, retention programs, and low salaries received whereas research conducted at private universities in Malaysia affirms that lecturers runoff caused by psychological reasons for instances: lack of support from superiors, job insecurity, unsatisfying compensation and getting no happiness (Rathakrishnan, Imm \& Kok, 2016). Nevertheless, today's businessman faces the same challenges as universities in stimulating employees' willingness to attract and retain (Qureshi, Marwat, \& Ramay, 2010). To achieve a competitive advantage, organizations should prioritize employee skills and quality to ensure sustainable performance (Harvey, 2009; Reiche, 2007). Maintaining capable employees is also a major strategic policy issue for 
many organizations (Heinan \& O'Neill, 2004; Bersin, 2008). Retaining quality staff is essential for keeping loyal customers as well as avoiding the costs of replacing the staff (Holbeche, 2009). Hence, the current study aimed to find out the private universities' strategy for lecturer's retention.

\section{METHODS}

The researcher refers to a qualitative approach due to using this approach helps the researcher to interact with the participants under the study and ask them questions to get a deeper meaning of different issues about factors that root lecturers alter association to others. The researcher interviewed eight (8) lecturers that had experiences crossing from one university to another. Eight lecturers spreader over the four private higher educations include STIKES Mandala Waluya Kendari, STIKES Avicenna Kendari, PPNI Kendari, and Pharmacy College Bina Husada Kendari. University administrators, for instance, rectors, deans, and heads of departments were also involved because by positions, they were influential in motivating and inducting lecturers.

The semi-structured interview used since a semi-structured interview is open rather than a structured interview (Daymon \&

Work, what they do not like, what makes them move, what makes them interested, what they hope, and etcetera. These questions intended to digging out some reasons that cause a lecturer who has undergone institutional transfer. The lecturer joins a college to get wages rather than as existence and contribute as their competences. Lecturers tend to prefer challenging assignments that will allow them to prove commitment fully and
Holloway, 2002). By using a semistructured interview researcher also can re-focus the questions or prompt for more information if something exciting or novel emerges. The interviewer conducted question-answer face to face while taking notes in the case where the recording device meets malfunctions. Besides, companion recording using phone-recorder. The definitive record of what the writer calls a transcript subsequently analyzed using the inductive model rather than deductive, which consists: cycling code, patterning code, jotting, memoing, and assertion and proposition development (Miles, Huberman, \& Saldana: 2014). Data Analysis made in parallel with data collection activities for making quick adjustments to study design as required. The validity and trustworthiness of the data, each the researchers and coresearchers interpreted findings and then looked for similarities and categorized them in a view theme (Halkier, 2011). The author also compared findings related to retention strategies with earlier studies

\section{RESULTS AND DISCUSSION}

\section{Results}

Strategy to retain lecturers was traced by asking what made them feel comfortable and eager to

demonstrate their skill and ability. Besides, all of the informants said that working without a pleasant working atmosphere and understanding leader is hopeless. They argued that being active on campus every day sometimes makes them have less enthusiastic about doing work. To build lecturers' excitement, indeed, much of motivations are needed-for example, comfortable together with the pleasant working room. 
By the question-answer sections, also found that being appreciated and respected surely increase their passion and loyalty. At the same time, it has been identified by all participants that brilliant career and certainly-sufficient salary they consider it to stay and survive. Some pointed out the shortage of well-resourced libraries.

After tracing the causes of the lecturer out, then data was analyzed to produce the authors' perception. Based on data processing, researchers pointed to a view motives as stored as in the following table:

Table 1. Description Factors Results

\begin{tabular}{|l|l|}
\hline Description & Theme \\
\hline $\begin{array}{l}\text { Lecturers work to get salaries so that they can fulfill family needs } \\
\text { every month. Therefore, the salary has given according to the } \\
\text { scheduled time. }\end{array}$ & Delay in payment \\
\hline $\begin{array}{l}\text { Lecturers will be happy if the leader administrates them. } \\
\text { Instead, the lecturer feels pressured if the leader being "bossy." }\end{array}$ & Leadership style \\
\hline $\begin{array}{l}\text { A position in the office will inevitably increase with time and } \\
\text { achievements. Researcher stuck due to administrative blocks }\end{array}$ & $\begin{array}{l}\text { Unclear career } \\
\text { Development }\end{array}$ \\
\hline $\begin{array}{l}\text { Carrying out the duties of the lecturer requires the support of a } \\
\text { pleasant atmosphere without pressure and adequate facilities. }\end{array}$ & $\begin{array}{l}\text { Conducive work } \\
\text { environment }\end{array}$ \\
\hline $\begin{array}{l}\text { As the responsibility of lecturers includes three pillars of higher } \\
\text { education, all of them require material to achieve it. The } \\
\text { lecturers have to look for literature outside the campus or } \\
\text { independently download books, journals, and others even often } \\
\text { spend their own money. }\end{array}$ & $\begin{array}{l}\text { Lack of adequate } \\
\text { well-resourced } \\
\text { libraries }\end{array}$ \\
\hline $\begin{array}{l}\text { The achievements made by lecturers merely end with personal } \\
\text { pride. Leaders are busy with their affairs without realizing if } \\
\text { lecturers need recognition of their achievements. }\end{array}$ & Lack of recognition \\
\hline $\begin{array}{l}\text { Lecturers' jobs are teaching, conducting research and } \\
\text { community service, and provide services to students. Everything } \\
\text { must arrange; thus, all can handle it. However, some of those } \\
\text { tasks sometimes have to be suspended later. }\end{array}$ & Heavy workload \\
\hline
\end{tabular}

\section{DISCUSSION}

The purpose of this study is to formulate a lecturer retention strategy in private higher universities. The prior studies at the same focus used to confirm findings in this current study. Authors themed lecturers' attrition reasons, for instance: delay in payment, leadership style, career development, conducive work environment, lack of adequate wellresourced libraries, lack of recognition, and over-workload.

Providing an elucidation of lecturers' resigning yet changing jobs as the main problem in this paper, here are some approaches that can take. Research IJEMI Vol. 1, No. 2, May 2020: 120 - 133 shows that the trend of redefining modern retention strategies by embracing lecturers' motivation is one of the key factors to meet the diversity and resilience in institutions (Thomas, 2000). The question of maintaining employee for a longer time requires the organization to produce an environment where employees are not only involved but have a sense of selfassurance and promising career (Chaminde, 2007). Even previous researchers agreed on the idea that successful organizations have an underlying philosophy to respect and invest in their best employees (Samuel, 2010; Nwokocha \& Iherirohanma, 2012). 
The retention strategy is not only a deal that must be considered by profit organizations, but also has become the business of non-profit organizations such as universities (Khalid, Irshad, \& Mahmood, 2012).

Employee retention is known as a critical key to the long-term health and success of any organization. Hence, failing to retain employee means an enormous loss for an organization. Agreed by Olowu \& Adamolekun (2005), it is becoming essential to secure and manage the competent human resource as the most valuable resource of any organization, because of the need for effective and efficient delivery of goods and services by organizations, whether in public or private sector. The present study found that the administrator was somewhat troublesome due to the lecturer left and decided to move to another campus. Cited of one the university administrators:

"A view of our long-outstanding lecturers decided to move. Of course, we felt a little worried about that because it was difficult to find the same substitute" (AU)

Overcoming problems faced by the university, here are some aspects that necessitate attention. To keep employees and remain satisfying high, $\mathrm{Ng}^{\prime}$ ethe et all. (2012) tried measuring the relationship between leadership style on academic staff retention and found the two variables were significant. Contrarily, Long, Thean, \& Jusoh (2012) set that leadership styles do not influence employee retention much. Meawhile, Spector (1997), argues leader and its skill in building a climate of employees' retention: encourages them to stay, will be an organization's best defense against unwanted turnover. Moreover, effective leaders pilot resources in an attitude allowing them to participate to gain the organization's overall aims (Mat, 2008). It strictly pressed leaders should focus not on compensation, promotion, and working conditions only but also on how leadership exercised since employees find it (Mwita, Mwakasangula \& Tefurukwa, 2018). Leadership refers to the relationship through which a person influences other people's behaviors or actions.

The leader employs its authority, managing people's heads to meet goals and maximizing results in an organization. Employ authority does not mean the leader was having power over the followers and controlling or directing them to personal purpose. Implying leadership must not only leader inspires subordinates through words but also calculated actions. They stated in the authors' interpretation result that: "lecturers expected to administrated, rather than being "bossed." One of the vital roles of a leader is to provide a work-life that would help the lecturer. It also includes triggering employees' decision to be loyal and stay in the college even when other jobs were waiting outside the institution. The leader also needs to implement each of the three employee retention: respect, recognition, and rewards (Mathimaran \& Kumar, 2017). Instead, Kevin, Joan \& Adrian's (2004) set leadership style can affect organizational commitment and work satisfaction positively.

Afterward, Work-life balance is increasingly important for engagement and affects retention. Hyman \& Summers (2003a). Wells \& Thelen (2002) have stated in their study that organizations that have generous human resource policies have an excellent chance to satisfy and retain employees by providing them an appropriate level of privacy and sound control on the work environment. Work-life balance is 
increasingly important for engagement and affects retention. Miller, Erickson \& Yust (2001) also state that employees get benefited from the work environment that provides a sense of belonging. Hyman \& Summers (2003b), in their empirical research in the UK, found that interventions of work demand into personal life (e.g., working during the weekend) resulted in heightened stress and emotional exhaustion among the employees.

Since revealed by the participants, the said if the work environment is conducive, it enhances the motivation levels to commit with the organization for the long term. The present study points the most significant finding; it is the fulfillment of the physical and non-physical work life. Both physical, non-physical are factors that can stimulate the positive energy of the lecturer. Work-life includes workplaces, facilities, tools, cleanliness, lighting, and tranquility. Stated by Jain, Ruchi \& Kaur (2014), there are two types in the work-life rope, namely the physical work and non-physical work environment. Lecturers hope that work-life at the campus can be a comfortable home for them.

The concept of the work environment divided into two aspects called the physical working environment and the nonphysical working environment (Suri et al., 2011). Given the amount of time people spend in the workplace, it is essential for employees to be satisfied and comfortable with their lives in the workplace (Sinha, 2012), because time pressure is a severe problem facing workers today (Glass \& Finley, 2002; Lippe, 2007). Physically, the lecturers expect a supportive workspace. Hence, they can provide maximum service to students. The availability of sufficient infrastructure will also boost their job satisfaction. Work-life quality is different from job satisfaction (Lawler, 1982). However, job satisfaction can be a variable or indicator to rate the quality of the work life (Cohen, Kinnevy \& Dichter, 2007). In terms of schooling, the workload would affect significant positively on teachers' work-life (Werang, 2018). Non-physical worklife includes interaction that harmoniously established among leader-lecturers and lecturers-students.

An indicator that often used to measure non-physical work environments is whether employees feel prized by the leader (Boxall, 2003). The psychological and social elements of the work environment include conflict, threat, workplace assault (Sell \& Cleal, 2011), workload, and stress levels experienced (Busck et al., 2010). Strictly, all personal in any organization must put respect, support, and not put pressure. The institutional leader can certainly reprimand subordinates as long as it has done to discipline or provides advice. As trusted literature, the workforce is psychologically competent, and it is proven to be able to perform better, commit toward more productive work than the employee who is psychologically depressed (Wright \& Bonett 2007; Wright \& Cropanzano 2004). Furthermore, the quality of the work-life will also imply the overall degree of quality of life (Sirgy et al., 2001).

At the same time, Messmer (2000) pointed out that one of the crucial factors in employee retention is an investment in employee training and career development. Meyer et al. (2003) also have shown internal career development of employees is often the best predictor of an employee's affective commitment. Hence, employees want career growth opportunities to develop and rise in their career ladder (Prince, 2005). They were boosting the lecturers' competence in line 
with career development. They aimed to accomplish a personal career as well as improving the institution's image. Lecturer's career development associates to help faculty members to improve their capacity to become more effective instructors, as well as perform other parts of their complex tasks, such as conducting research, contributing to administrative activities, and writing publishable materials. Lecturer's career development intended to form the character of the foundation for the lecturer. Thus, they do not immediately satisfy themselves with their achievements. Lecturers expected to change more advanced, working hard for perfecting their abilities to prove the professionalism in teaching, educating, and researching. The career itself can interpret as an employee's work journey within the organization (Nacif, 2006).

Meanwhile, Gardner, Van \& Pierce (2004) have a sight that pays considered as a motivator as well as employee retention technique. Furthemore, Milkovich \& Newman (2004) have clearly stated that among all types of reward, monetary pay is considered one of the most important and significant factors in retention. Pay itself not just paid, must be by the contract; on time. Payroll delay affected to lecturers' standard of living and cause multiple socioeconomic problems that have adversely result in their performances. By the participant's statements in the current study, they highlight that the problem will begin coming when payment in the exact amount due by the date shown on the statement is not received. Disagreements then lead to arguments as relationships sour, and the stage set for distrust. The possible impacts of delayed payment carried out by Previous studies such as: create a negative chain effect (Landon \& Consultancy, 2003), affects the progress of the works and profitability (Naseem, 2005), delay in completion of programs, in addition to workforce shortage (Rahman \& Berawi, 2006).

To sum up, appropriate human resource management strategies and policies implemented effectively can significantly assist managers in dealing with the employee retention challenges ahead. Human resources management also emphasized promoting, valuing, treating all individuals with dignity, respect, fairness, and recognizing academic staff. Finally, management practices can help improve absenteeism, employee retention, and better quality of work (Irshad, 2011).

\section{CONCLUSION AND SUGGESTION}

The growth of private higher education leaves many problems. They face challenges since the demand for the best services coming from its consumers. One of the challenges is maintaining a qualified lecturer. It has become a challenge as the appearance of new colleges. On the other hand, the availability of capable lecturer gradually decreased as well.

Moreover, many private higher educations' even dare to promise more benefits for the lecturer. Lecturer's retention will become more vital in the competition. Before arriving at the strategy that will take to attract and maintain the lecturers. The human resources division of Higher education needs to examine reasons that trigger the lecturer to move. Whenever a lecturer resigns

According to the present study, the private higher university must put more concern about payment, leadership style, career development, conducive-work life, adequate well-resourced libraries, recognition, and workload to its lecturers. The authors contend that lecturer retention allows the institution and its human 
resources division to attract and effectively retain critical skills and high performing lecturers. The objective of retention policies should be to identify and retain committed employees for as long as it is mutually profitable to the institution and the lecturers.

$\mathrm{Al}$ in all, the author calls private higher educations to review their strategies to magnetize interest and retaining lecturer. Besides, the researcher hopes that there will be further research to test the conclusions rooted in the quantitative approach.

\section{Acknowledgments}

The authors would like to express gratitude to those who have helped in conducting the research. To the team of promotors who directed and provided guidance, the participants at the research. The rector and the community of the Muhammadiyah University of Kendari, and Kemenristek DIKTI.

\section{REFERENCE}

Barber, M., Donnelly, K., \& Rizvi, S. (2013). An avalanche is coming: Higher education and the revolution ahead. Retrieved from: http://med.stanford.edu/smili/s upport/FINAL\%20Avalanche\%2 OPaper\%201 10313\%20\%282\%29. pdf

Bersin, J. (2008). The Business Impact of Talent Management. Banking Strategies, 84(5), pp. 6.

Bratianu, Constantine. 2005. The Intellectual Capital of Universities. Bucharest: Academy of Economic Studies. https://www.researchgate.net/ publication/41163644
Busck, O., Knudsen, $H_{\text {., }}$ and Lind, J. (2011). "The transformation of employee participation: Consequences for the work environment." Economic and Industrial Democracy, 31, 285305.

Doi.org/10.1177/0143831X093512 12.

Boxall, P., Macky, K., and Rasmussen, E. (2003). 'Labour turnover and retention in New Zealand: The causes and consequences of leaving and staying with employers. Asia Pacific Journal of Human Resources, 41, 195214. doi.org/10.1177/10384111030412 006.

Calhoun, T. (2009). Lecturers' Job Satisfaction and Employees Turnover. MichiganStates: USA.

Cassidy, D.J. (2011). The day to day reality of teacher turnover in preschool classrooms: An analysis of classroom context and teacher, director, and parent perspectives. Journal of Research in Childhood Education, 25(1), 1-21. DOI: 10.1080/02568543.2011.533118.

Chaminade, B. (2007). A Retention Checklist: How Do You Rate? Retrieved on 11th March 2019, from

www.humanresourcesmagazine .co.au.

Cohen, B. J., Kinnerya, S. C., and Dichtera, M. E. (2007). The quality of work-life of child protective investigators: A comparison of 
two work environments.

Children and Youth Services

Review, vol 29 (4). doi.org/10.1016/j.childyouth.200 6.09.004.

Chipunza, C., Samuel, M.O. (2009). Employee retention and turnover: using motivational variables as a panacea. African Journal of Business Management, 3(8), 410-415. https://www.researchgate.net/ publication/228654630.

Daymon, C., \& Holloway, I. (2002). Qualitative research methods in public relations and marketing communications. New York, NY: Routledge.

https://epdf.pub/qualitativeresearch-methods-in-publicrelations-and-marketingcommunications-2n.html.

Edy S. (2017). Dampak Kinerja Dosen dengan Adanya Program Peningkatan Mutu Serta Motivasi Kerja di STIE Amkop Makassar. Jurnal IImiah Aksi STIE Amkop Makassar, 4(1): 384-389. https://docplayer.info/3052799

5.

Gardner DG, Van Dyne L, \& Pierce JL. (2004). The effects of pay level on organization-based selfesteem and performance: a field study. Journal of Occup. Organ. Psychology, 77(3): 307 322.

https://doi.org/10.1348/0963179 041752646

Glass, J. L., \& Finley, A. (2002). Coverage and effectiveness of familyresponsive workplace policies.
Human Resource Management

Review, 12, 313-337.

doi.org/10.1016/S1053-

4822(02)00063-3.

Irshad, M. (2011). Factors affecting employee retention: evidence from the literature review. Abasyn Journal of Social Sciences. 2011;4(1).

Halkier, B. (2011). Methodological practicalities in analytical generalization. Qualitative Inquiry, 17(9), 787-797. DOI: $10.1177 / 1077800411423194$.

Harvey, D. (2009). Talent Strategy is Vital-Personnel Today, June 23, 13.

Heinen, J. S., and O'Neill, C. (2004). Managing talent to maximize performance. Employment Relations Today, 31 (2), pp. 67-82. https://doi.org/10.1002/ert.20018

Holbeche, L. (2009). Aligning Human Resources and Business Strategy. (2nd ed.) Oxford: Elsevier. https://www.amazon.com/Align ing-Resources-Business-StrategySecond/dp/0750680172.

Hyman, J. \& Summers, J. (2004). Lacking balance? Work-life employment practices in the modern economy. Personnel Review, Vol. 33, pp. 418-29. https://doi.org/10.1 108/0048348 0410539498

Jain, Ruchi \& Kaur, S. (2014). Impact of Work Environment on Job Satisfaction. International Journal of Scientific and 
Research Publication, 4(1), 1-8. https://doi.org/ISSN 2250-3153.

Kemenristek DIKTI. (2017). Statistik Pendidikan Tinggi: Higher Education Statistical Year Book 2017. Jakarta Pusat: Pusat Data dan Informasi Iptek Dikti.

Kemenristek DIKTI. (2018). Persyaratan dan Prosedur Penggabungan dan Penyatuan Perguruan Tinggi Swasta. Jakarta Pusat: RISTEKDIKTI.

Kevin, MM, Joan LC, \& Adrian JW. (2004). Organizational change and employee turnover. Personnel Review. 33 (2):161166.

https://doi.org/10.1 108/0048348 0410518022

Khalid, S., Irshad, M. Z., and Mahmood, B. (2012). Job Satisfaction among Academic Staff: A Comparative Analysis between Public and Private Sector Universities of Punjab, Pakistan. International Journal of Business and Management, 7(1), pp. 126-136. Doi: 10.5539/ijbm.v7n 1p126

Khan, Z., Ahmed, J. U., \& Sarker, S. (2010). Faculty Mobility in the Private Universities: In Developing Country Context. KASBIT Business Journal, 3(1), 724.

https://kasbit.edu.pk/KBJVol3/7 -24-3(1)\%202010Jashim\%20uddin-.pdf

Langdon, Davis \& Consultancy, Seah (2003). Construction payment blues. Why that domino effect?
Executive Summary for the Practitioner, 3 (3).

Lawler, E., \& Fuchs, K. (2010). Cornell University, at its Sesquicentennial Strategic Plan for lecturers' retention. Washington: Washington University.

Lawler, E. (1982). Strategies for improving the quality of work life. American Psychologist, 37, pp. 66-73. Doi.org/10.1037/0003066X.37.5.486.

Lippe, Van der, T. (2007). Dutch workers and time pressure: Household and workplace characteristics. Work, Employment and Society, 21(4), 693-711. DOI: $10.1177 / 0950017007082877$.

Long, C.S., Thean, L.Y., Ismail, W.K., \& Jusoh, A. (2012). Leadership Styles and Employees' Turnover Intention: Exploratory Study of Academic Staff in a Malaysian College. World Applied Sciences Journal, 19(4),575-581. DOI: 10.5829/idosi.wasj.2012.19.04.155

Mat, Jan. (2008). The Influence of Leadership Style on Internal Marketing in Retailing (Ph.D. Thesis). The University of Stirling. https://pdfs.semanticscholar.org /de43/1179860d78f831a6bbl 777 380890e501 1flb.pdf.

Mathimaran. B., K.\& Kumar, A., A. (2017). Employee Retention Strategies Empirical Research. Global Journal of Management and Business Research: E-Marketing, Volume 17, Issue 1, Version 1.0. https://globaljournals.org/GJMB 
R_Volume17/3-Employee-

Retention-Strategies.pdf

Maqsood, H., Amran, R., Chaudhry, S., A., Rosman, B., M., Y., Omair, M., A., A., Ahmed, ., \& Shaheryar, N.,F.,T, (2015). The Impact of Human Resource Practices on Employee Retention in the Telecom Sector. International Journal of Economics and Financial Issues, 2015, 5 (Special Issue)

63-69. https://www.econjournals.com/ index.php/ijefi/article/view/134 4.

Messmer, M. (2000). Orientations programs can be key to employee retention. In Strategic $\begin{array}{lll}\text { Finance. } \quad 81 & (8): 12-15 .\end{array}$ http://www.scirp.org/(S (i43dyn4 5 teexjx455qlt3d2q))/reference/ ReferencesPapers.aspx? Refere ncelD $=1768991$.

Meyer, John, Laryssa Topolnytsky, Henryk Krajewski \& Ian Gellatly. (2003). Best Practices: Employee Retention. Toronto: TomsonCarswell.

Michael, S., O. (2008). Using Motivational Strategy as Panacea for Employee Retention and Turnover in Selected Public and Private Sector Organisations. International Journal of Science and Research (IJSR), Volume 5, Issue 1. Paper ID: NOV152642 415

Miles, Matthew B., A. Michael Huberman, and Johnny Saldana. (2014). Qualitative Data Analysis: A Methods
Sourcebook. Thousand Oaks, CA: Sage. https://www.amazon.com/Quali tative-Data-Analysis-MethodsSourcebook/dp/1452257876

Miller, N., Erickson, A., \& Yust, B. (2001). Sense of place in the workplace: The relationship between personal objects and job satisfaction and motivation. Journal of Interior Design, 27(1), 35-44.

Milkovich, GM, \& Newman, JM. (2004). Compensation (8th ed.). Burr Ridge, IL: Irwin McGraw-Hill.

Mkulu, G., Demetria. (2018). Academic staff retention in Private Universities in Southern Highland Zone Tanzania as a Strategy of Attaining Sustainable Development. International Journal of Humanities and Social Science. Vol. 8, No. 5. Doi:10.30845/ijhss.v8n5p17.

Mok, Ka-Ho. (2005). Globalization and educational restructuring: University merging and changing governance in China. Higher Education, 50: 57-88. DOI: 10.1007/s10734-004-6347-z.

Mwita, M., K., Mwakasangula, E., \& Tefurukwa, Oscar. (2018). The Influence of Leadership on Employee Retention in Tanzania Commercial Banks. International Journal of Human Resource Studies, ISSN 2162-3058 2018, Vol. 8 , No. 2. https://www.researchgate.net/ publication/324985158.

Nacif, A.P. (2006). The fast buck is still 
king: How to engage temporary staff with the brand and get the best out of them is a major HR challenge. Human Resource, 38(1), 263-290. DOI: $10.1177 / 0972150916666879$

Naseem, N.A. (2005). Construction Industry Payment and Adjudication Act: International Forum on Construction Industry Payment Acts and Adjudication. Kuala Lumpur: CIDB and ISM. https://www.researchgate.net/ publication/228461379.

Ng'ethe, J., Muceke, J., \& Iravo, M. A. (2012). Influence of Leadership Style on Academic Staff Retention in Public Universities in Kenya. International Journal of Business and Social Science, 3(21), 297-302. Retrieved from ijbssnet.com/journals/Vol_3_No _21__November_2018/31.pdf

Nwokocha, I., and Iherirohanma, B. J. E. (2012). Emerging Trends in Employee Retention Strategies in a Globalizing Economy: Nigeria in Focus. Asian Social Science, 8(10), pp. 198-207. DOI: 10.5539/ass.v8n10p198

Olowu, D.,\& Adamolekun, L. (2005). Human Resource Management. In L.Adamolekun (ed) Public Administration in Africa: Main Issues and Selected Country Studies. Ibadan: Spectrum Books.

Owuor, B.(2010). Academic mobility and brain drain: East African Perspective (paper presented at the director of international relations and partners). Nairobi: Maseno University.

Pinheiro, R., Geschwind, L., \& Aarrevaara, T. (2015). Mergers in higher education: The experience from Northern Europe. Dordrecht: Springer. https://www.springer.com/gp/b ook/9783319219172.

Qureshi, T. M., Marwat, Z. A., \& Ramay, M. I. (2010). Impact of Human Resource Management (HRM) Practices on Employees Performance A Case of Pakistan Telecom Sector. MA Jinnah University, Department of Business Administration and Social Sciences, Islamabad.

Rahayuningtyas, A., D., Prihatni \& Triana, Eka. (2017). Modal Intelektual dan Daya Saing Perguruan Tinggidi Indonesia. Jurnal Akuntansi dan Investasi, Vol. 18 No. 2. DOI: 10.18196/jai. 180279.

Rahman, M., \& Chowdhury, S. (2012). Job Satisfaction and Teachers' Turnover: A Study on Private Universities in Bangladesh. Bangladesh Research Publications Journal, 7(2), 142152. https://www.researchgate.net/ publication/262011439.

Rahman, H., Rahman \& Berawi, M.A. (2006). Delay mitigation in the Malaysian construction industry. Journal of Construction, Engineering, and Management, $\begin{array}{lll}\text { ACSE, } & 132 & \text { (2): } 125-133 .\end{array}$ Doi/abs/10.1061/(ASCE)0733- 
9364(2006) 132\%3A2(125).

Samuel, J .Chipunza. (2010). An Examination of Employee Retention Strategy in a private Organisation in Zimbabwe. African Journal of Business Management, 4 (10), 21032109, 2010. http://www.academicjournals. org/AJBM

Rasli, A.M., Norhalim, N., Kowang, T.O., Qureshi, M.I. (2014). Applying managerial competencies to overcome business constraints and create value evidence from small technology-based firms in Malaysia. Journal of Management Info, 3(1), 99-121. http://readersinsight.net/jmi/arti cle/view/15.

Rathakrishnan, T., Imm, Ng., S., \& Kok, K., Tee. (2016). Turnover Intentions of Lecturers in Private Universities in Malaysia. Social Sciences \& Humanities. Pertanika J. Soc. Sci. \& Hum. 24 (S): $129-146 \quad$ (2016). https://www.researchgate.net/ publication/317212947.

Reiche, S. (2007). The effect of International Staffing Practices on Subsidiary Staff Retention in Multinational Corporations. The International Journal of Human Resource Management, 18(4), pp. 523-536. https://doi.org/10.1080/0958519 0601178711.

Sell, L., and Cleal, B. (2011). 'Job satisfaction, work environment, and rewards: Motivational theory revisited.' Labour, 52, 1-
23. DOI: $\quad 10.1111 / j .1467-$ 9914.2010.00496.x

Sinha, Chandranshu. (2012). Factors Affecting Quality of Work Life: Empirical Evidence From Indian Organizations. Australian Journal of Business and Management Research, Vol.1 No.11 [31-40]. https://www.researchgate.net/ publication/259761949.

Sirgy, M.J., Efraty, D., Siegel, P., and Lee, D. J. (2001). A New Measure of Quality of Work Life (QWL) Based on Need Satisfaction and Spillover Theories. Social Indicators Research, Vol. 55, No. 3, pp 241-302. DOI: 10.1023/A:1010986923468.

Stauss, B., Chojnacki, K., Decker, A., Hoffman, F. (2001). Retention effects of a customer club. International Journal of Service Industry Management, Vol. 12 No.1 pp.7-19. https://doi.org/10.1108/0956423 0110382745

Spector, P. E. (1997). Job satisfaction: Application, assessment, causes, and consequences. Thousand Oaks, CA: Sage Publications, Inc. http://sk.sagepub.com/books/jo b-satisfaction.

Thomas, Kenneth W. (2000). Intrinsic motivation at work building energy and commitment. San Francisco: Berrett-Koehler.

Tim Pengkaji Kebijakan DIKTI. (2018). Kajian Pendidikan Tinggi IDRI untuk DPR RI dan Ristek Dikti 2018. Bandung: ITB Pres. 
Undang-undang Dikti No. 12 tahun 2012 tentang Pendidikan Tinggi.

Prince, B.J. (2005). Career-focused employee transfer processes. Career Development International, 10(4), 293-309. DOI/abs/10.1108/136204305106 09136.

Wells, M., \& Thelen, L. (2002). What does your workspace say about you? The influence of personality, status, and workspace on personalization. Environment and Behavior, 3: 300-321. https://doi.org/10.1177/0013916 502034003002

Werang, Redan Basilius. (2018). The Effect of Workload, Individual Characteristics, and School Climate on Teachers' Emotional Exhaustion in Elementary Schools of Papua. Cakrawala Pendidikan, Edisi Oktober 2018, the.xxxvii, no.3. https://journal.uny.ac.id/index. php/cp/article/view/20635.

Wisnefski, M. (2008). Employee retention in the new millennium. Business Services, 16(3), 465-507.

Wright, T.A. \& Cropanzano, R. (2004). The Role of Psychological WellBeing in Job Performance: A Fresh Look at an Age-Old Quest. Organizational Dynamics, Vol. 33, No 4, pp 338-351. https://psycnet.apa.org/record /2005-00155-003.

Wright, T.A. \& Bonett, D.G. (2007). Job Satisfaction and Psychological Well-Being as Non-additive Predictors of Workplace
Turnover. Journal of Management, Vol. 33, No. 2, pp 141-160. DOI: $10.1177 / 0149206306297582$.

Zeeman, N., \& Benneworth, Paul. (2017). Globalization, mergers, and 'inadvertent multi-campus universities': reflections from Wales. Tertiary Education and Management, 23:1, 41-52. DOI: 10.1080/13583883.2016.1243256. 